\title{
Malic enzyme is a major source of NADPH for lipid accumulation by Aspergillus nidulans
}

\author{
James P. Wynn and Colin Ratledge
}

Department of Biological Sciences, University of Hull, Hull HU6 7RX, UK

\author{
Author for correspondence: James P. Wynn. Tel: +44 1482 465507. Fax: +441482465458. \\ e-mail: j.p.wynn@biosci.hull.ac.uk
}

Keywords: lipid biosynthesis, malic enzyme, Aspergillus nidulans

\section{INTRODUCTION}

Malic enzyme [malate dehydrogenase (decarboxylating) $\left.\left(\mathrm{NADP}^{+}\right)(\mathrm{EC} 1.1 .1 .40)\right]$ catalyses the reaction:

$\mathrm{L}$-malate $+\mathrm{NADP}^{+} \rightarrow$ pyruvate $+\mathrm{CO}_{2}+\mathrm{NADPH}$

This enzyme has been detected in a range of fungi though its cellular function remains obscure. Some authors report that its main function is in the metabolism of pyruvate (McCullough \& Roberts, 1974; Zink, 1972; Zink \& Katz, 1973) whilst others have presented evidence that malic enzyme is also a major source of NADPH for de novo lipid biosynthesis and desaturation (Evans \& Ratledge, 1985; Kendrick \& Ratledge, 1992a).

In this communication the importance of malic enzyme with respect to lipid metabolism in Aspergillus nidulans has been investigated. This fungus was chosen because it is oleaginous, accumulating up to $25 \%$ of its dry weight as lipid (Sharma et al., 1981), and mutants with altered malic enzyme activities are available (McCullough \& Roberts, 1974).

\section{METHODS}

Chemicals. All fine chemicals were obtained from Sigma. Sodium salts were used throughout.

Maintenance of fungi. The three strains of $A$. nidulans used were auxotrophic with regard to $p$-aminobenzoic acid. Strain pabaA1 was unaffected with respect to its malic enzyme activity and is described throughout as wild-type. The other two strains were mutants unable to utilize acetate, originally produced by McCullough and co-workers (McCullough \& Roberts, 1974; Armitt et al., 1976). One of these, acuK248, was reported to lack malic enzyme activity, whilst the other, acuF205, has been reported to possess elevated malic enzyme activity (McCullough \& Roberts, 1974). The mutants were routinely maintained on Pontecorvo medium agar plates (Pontecorvo et al., 1953) and were stored at $4{ }^{\circ} \mathrm{C}$.

Production of conidial suspensions. Conidia were harvested in $0.8 \%(\mathrm{w} / \mathrm{v})$ Tween 80 . Conidia were dislodged from the surface of agar plates by gentle rubbing with a sterile cotton bud. The harvested conidia from a number of plates were pooled and sedimented by centrifugation at $10000 \mathrm{~g}$ for $5 \mathrm{~min}$ at $4{ }^{\circ} \mathrm{C}$. The conidial pellet was suspended in a small volume of $0.8 \%$ Tween 80 and the conidial concentration determined using a Thoma counting chamber.

Cultivation of fungal biomass. The fungus was grown in 1 litre Erlenmeyer flasks containing $200 \mathrm{ml}$ liquid medium at $37^{\circ} \mathrm{C}$, with constant shaking at $145 \mathrm{r}$.p.m. The medium used was that of Das \& Sen (1983) containing $\left(\mathrm{g} \mathrm{l}^{-1}\right)$; glucose, 40; $\mathrm{NaNO}_{3}, 2 ; \mathrm{MgSO}_{4} .7 \mathrm{H}_{2} \mathrm{O}, 0.5 ; \mathrm{KCl}, 0.5 ; \mathrm{ZnSO}_{4} .7 \mathrm{H}_{2} \mathrm{O}, 0.01$; $\mathrm{FeSO}_{4} .7 \mathrm{H}_{2} \mathrm{O}, 0.01$; and $p$-aminobenzoic acid, 0.002 . This medium was designated HAM ('high-nitrogen' Aspergillus medium). When high lipid yields were required the medium was modified by decreasing the amount of $\mathrm{NaNO}_{3}$ to $1 \mathrm{~g} \mathrm{l}^{-1}$; this medium was designated LAM ('low-nitrogen' Aspergillus medium). Culture flasks were inoculated with either $0.5 \times 10^{6}$ or $3 \times 10^{6}$ conidia $\mathrm{ml}^{-1}$.

Production of cell extracts. Mycelia were harvested by filtration and washed with distilled $\mathrm{H}_{2} \mathrm{O}$. Samples of the culture filtrate were retained for separate analysis, being stored at $-21{ }^{\circ} \mathrm{C}$ if necessary. Biomass was suspended in $100 \mathrm{mM} \mathrm{KH}_{2} \mathrm{PO}_{4} / \mathrm{KOH}$ buffer $(\mathrm{pH} 7.5)$ containing $20 \%$ (w/v) glycerol, $1 \mathrm{mM}$ benzamidine and $1 \mathrm{mMDTT}$ and disrupted by passage twice through a French press at $35 \mathrm{MPa}$. The resulting homogenate was centrifuged at $15000 \mathrm{~g}$ for $10 \mathrm{~min}$ at $4^{\circ} \mathrm{C}$ and the supernatant used to determine enzyme 
Table 1. Enzyme activities in A. nidulans grown on 'high-nitrogen' medium (HAM) for $40 \mathrm{~h}$

Activities are presented as mean values \pm standard error of the mean $(n=3)$ for replicate assays of a single extract. The experiment was repeated three times using extracts prepared from separate cultures; typical data are presented. ND, Activity not detected.

\begin{tabular}{|c|c|c|c|}
\hline \multirow[t]{2}{*}{ Enzyme } & \multicolumn{3}{|c|}{ Enzyme specific activity $\left[\mu \mathrm{mol} \mathrm{min}^{-1}(\mathrm{mg} \text { protein })^{-1}\right]$} \\
\hline & Wild-type & acuF205 & acuK248 \\
\hline $\mathrm{ME}$ & $0.011 \pm 0.003$ & $0.016 \pm 0.040$ & ND \\
\hline $\mathrm{ACL}$ & $0.051 \pm 0.002$ & $0.050 \pm 0.006$ & $0.050 \pm 0.003$ \\
\hline 6-PGDH & $0 \cdot 260 \pm 0.030$ & $0.296 \pm 0.062$ & $0.313 \pm 0.040$ \\
\hline G-6-PDH & $1.073 \pm 0.031$ & $1 \cdot 170 \pm 0 \cdot 115$ & $1 \cdot 590 \pm 0.195$ \\
\hline $\mathrm{MDH}$ & $8 \cdot 540 \pm 0 \cdot 193$ & $9 \cdot 709 \pm 0 \cdot 271$ & $9.754 \pm 0.676$ \\
\hline $\mathrm{NADP}^{+}: \mathrm{ICDH}$ & $0.071 \pm 0.005$ & $0.060 \pm 0.002$ & $0.090 \pm 0.008$ \\
\hline PC & $0.031 \pm 0.003$ & $0.030 \pm 0.003$ & $0.006 \pm 0.001$ \\
\hline $\mathrm{PDH}$ & ND & ND & ND \\
\hline PDC & $0.005 \pm 0.001$ & $0.010 \pm 0.002$ & $0.001 \pm 0.001$ \\
\hline
\end{tabular}

*ME, malic enzyme; ACL, ATP:citrate lyase; 6-PGDH, 6-phosphogluconate dehydrogenase; G-6$\mathrm{PDH}$, glucose-6-phosphate dehydrogenase; $\mathrm{MDH}$, malate dehydrogenase; $\mathrm{NADP}^{+}: \mathrm{ICDH}_{\mathrm{NADP}}$ dependent isocitrate dehydrogenase; PC, pyruvate carboxylase; PDH, pyruvate dehydrogenase; PDC, pyruvate decarboxylase.

activities. Protein concentrations were determined according to Bradford (1976), with BSA as a standard.

Estimation of enzyme activities. All enzyme activities were determined using continuous spectrophotometric assays following the oxidation or reduction of $\operatorname{NAD}(\mathrm{P})(\mathrm{H})$ at $340 \mathrm{~nm}$, within $2 \mathrm{~h}$ of extract preparation. All assays were carried out at $37^{\circ} \mathrm{C}$.

Enzyme assays were, with the exception of that for NADP $^{+}$dependent isocitrate dehydrogenase, carried out as described in the literature with only minor alterations: malic enzyme was assayed as described by Hsu \& Lardy (1969) with malate at $25 \mathrm{mM}$; ATP : citrate lyase as described by Srere (1959) at pH 8.6; 6-phosphogluconate dehydrogenase as described by Potremoli \& Grazi (1966); glucose-6-phosphate dehydrogenase as described by Langdon (1966); malate dehydrogenase as described by Ochoa (1955); pyruvate decarboxylase and pyruvate dehydrogenase as described by Reed \& Willms (1966); pyruvate carboxylase as described by Seubert \& Weicker (1969). The assays for ATP: citrate lyase, pyruvate carboxylase, pyruvate decarboxylase and pyruvate dehydrogenase were supplemented with $10 \mathrm{mM}$ sodium azide, to inhibit NADH oxidase.

$\mathrm{NADP}^{+}$-dependent isocitrate lyase activity was determined using an assay system containing $82 \mathrm{mM}$ Tris/ $\mathrm{HCl}(\mathrm{pH} 8.0)$, $3 \mathrm{mM} \mathrm{MgCl}_{2}, 0.24 \mathrm{mM} \mathrm{NADP}+, 5 \mathrm{mM}$ isocitric acid.

Determination of culture dry weights. Ten millilitres of a shake-flask culture was filtered through pre-weighed filter circles (Whatman no. 1), washed with distilled $\mathrm{H}_{2} \mathrm{O}$, then dried at $100^{\circ} \mathrm{C}$ for $48 \mathrm{~h}$ and reweighed.

Analysis of culture filtrates. Glucose concentrations were determined using a GOD Perid test kit (Boehringer Mannheim). Citrate concentrations were determined using the method of Williamson \& Corkey (1969). Malate concentrations were determined using an assay containing: $87 \mathrm{mM} \mathrm{KH}_{2} \mathrm{PO}_{4} / \mathrm{KOH}$ buffer (pH 7.5), $3 \mathrm{mM} \mathrm{MgCl}$, $0.5 \mathrm{mM} \mathrm{NADP}^{+}, 0.1$ unit malic enzyme (chicken liver). The assay was initiated by the addition of $100 \mu$ culture filtrate and incubated at $30^{\circ} \mathrm{C}$ for $20 \mathrm{~min}$. The $A_{340}$ was determined against a reagent blank.

Lipid analysis. Freeze-dried mycelia were extracted with $2: 1$ (v/v) chloroform/methanol (Folch et al., 1957) and the lipid content of the biomass determined gravimetrically. Fatty acids were methylated using trimethylsulphonium hydroxide (Butte, 1983) and analysed by GC using a packed column $(200 \times 0.4 \mathrm{~cm}, 10 \%, \mathrm{w} / \mathrm{w}$, diethylene glycol succinate and $1 \%$, w/w, $\mathrm{H}_{3} \mathrm{PO}_{4}$ on Chromosorb W-AW 80/100 mesh; Alltech Associates). The column was run at $200^{\circ} \mathrm{C}$ with the injector and detector at $230^{\circ} \mathrm{C}$. Fatty acid methyl esters were identified by comparison with authentic standards.

Whole-cell lipid was separated into neutral, sphingolipid plus glycolipid, and polar lipid fractions (Kendrick \& Ratledge, 1992b).

\section{RESULTS}

\section{Enzymological analysis}

For the estimation of enzyme activities in A. nidulans, a 'high-nitrogen' medium (HAM) was inoculated with $0.5 \times 10^{6}$ conidia $\mathrm{ml}^{-1}$ and incubated for $40 \mathrm{~h}$. Malic enzyme was readily detected, albeit at relatively low activity, in both the wild-type $\left[11 \mathrm{nmol} \mathrm{m^{-1 }}(\mathrm{mg}\right.$ protein) $\left.{ }^{-1}\right]$ and $a c u F 205\left[16 \mathrm{nmol} \mathrm{min}^{-1}(\mathrm{mg} \text { protein })^{-1}\right.$, but was undetectable in extracts prepared from $A$. nidulans acuK248 (see Table 1).

Other enzyme activities that were also measured (see Table 1) were: ATP: citrate lyase, which is involved in lipid accumulation; glucose-6-phosphate dehydrogenase, 6-phosphogluconate dehydrogenase and $\mathrm{NADP}^{+}$. dependent isocitrate dehydrogenase, which are NADPH generators; and pyruvate dehydrogenase, pyruvate carboxylase and pyruvate decarboxylase, which are involved in pyruvate metabolism. 
Table 2. Analysis of growth and lipid accumulation by $A$. nidulans

Data are presented as mean values \pm standard error $(n=3)$.

\begin{tabular}{|c|c|c|c|}
\hline & Wild-type & acuF205 & $a c u K 248$ \\
\hline \multicolumn{4}{|c|}{ Grown on 'high-nitrogen' medium (HAM) for $40 \mathrm{~h}$} \\
\hline Initial glucose $\left(\mathrm{g} \mathrm{l}^{-1}\right)$ & $46 \cdot 2 \pm 0 \cdot 2$ & $46 \cdot 2 \pm 0 \cdot 2$ & $46 \cdot 2 \pm 0 \cdot 2$ \\
\hline Residual glucose $\left(\mathrm{g} \mathrm{l}^{-1}\right)$ & $41 \cdot 1 \pm 1 \cdot 0$ & $35 \cdot 1 \pm 0 \cdot 7$ & $38.7 \pm 0 \cdot 9$ \\
\hline Cell dry weight $\left(\mathrm{g} \mathrm{l}^{-1}\right)$ & $1 \cdot 6 \pm 0 \cdot 5$ & $2 \cdot 9 \pm 0 \cdot 4$ & $1 \cdot 8 \pm 0 \cdot 3$ \\
\hline Cell lipid (\%,w/w, of dry weight) & $4 \cdot 5 \pm 0 \cdot 7$ & $4 \cdot 7 \pm 1 \cdot 2$ & $3 \cdot 8 \pm 1 \cdot 6$ \\
\hline Malate in culture filtrate $\left(\mathrm{mg} \mathrm{l}^{-1}\right)$ & $17 \cdot 6 \pm 0 \cdot 8$ & $30 \cdot 2 \pm 3 \cdot 7$ & $15 \cdot 6 \pm 0 \cdot 9$ \\
\hline Cell yield [g dry weight (g glucose used $\left.)^{-1}\right]$ & 0.31 & $0 \cdot 26$ & $0 \cdot 24$ \\
\hline \multicolumn{4}{|c|}{ Grown on 'low-nitrogen' medium (LAM) for $70 \mathrm{~h}$} \\
\hline Initial glucose $\left(\mathrm{g} \mathrm{l}^{-1}\right)$ & $44 \cdot 6 \pm 0 \cdot 1$ & $44 \cdot 6 \pm 0 \cdot 1$ & $44 \cdot 6 \pm 0 \cdot 1$ \\
\hline Residual glucose $\left(\mathrm{g} \mathrm{l}^{-1}\right)$ & $27 \cdot 0 \pm 0 \cdot 2$ & $30 \cdot 4 \pm 1 \cdot 6$ & $25 \cdot 9 \pm 0 \cdot 0$ \\
\hline Cell dry weight $\left(\mathrm{g} \mathrm{l}^{-1}\right)$ & $3 \cdot 8 \pm 0 \cdot 2$ & $4 \cdot 9 \pm 0.3$ & $5 \cdot 1 \pm 0 \cdot 1$ \\
\hline Cell lipid (\%,w/w, of dry weight) & $26 \cdot 5 \pm 1 \cdot 6$ & $23 \cdot 5 \pm 2 \cdot 7$ & $12 \cdot 4 \pm 1 \cdot 7$ \\
\hline Malate in culture filtrate $\left(\mathrm{mg} \mathrm{l}^{-1}\right)$ & $26 \cdot 5 \pm 1 \cdot 6$ & $72 \cdot 7 \pm 0 \cdot 6$ & $138 \cdot 8 \pm 3 \cdot 7$ \\
\hline Cell yield [g dry weight ( $\mathrm{g}$ glucose used $\left.)^{-1}\right]$ & 0.22 & 0.34 & 0.28 \\
\hline
\end{tabular}

\section{Lipid analysis}

Analysis of the cellular lipid when A. nidulans was grown on 'high-nitrogen' medium demonstrated very little difference between the wild-type and mutant strains (see Tables 2 and 3). The amount of lipid accumulated was low, approximately $5 \%(\mathrm{w} / \mathrm{w})$ of dry weight, and the fatty acyl composition of the cell lipids was similar (see Table 3). The predominant fatty acids were $16: 0,18: 0,18: 1$ and $18: 2$ (all $>5 \%, w / w$, of the total lipid). Notably, the 18:2 content of the cell lipid was very high in all cases, constituting approximately $60 \%(w / w)$ of the total cell fatty acids.

When the wild-type was cultivated from an inoculum of $3 \times 10^{6}$ conidia $\mathrm{ml}^{-1}$ for $70 \mathrm{~h}$ on the 'low-nitrogen' medium (LAM), to encourage lipid accumulation, analysis demonstrated both quantitative and qualitative changes in the cell lipid. The total lipid had increased to $26 \%$ $(\mathrm{w} / \mathrm{w})$ of the cell dry weight and the fatty acyl composition of this lipid was different from that of lipid produced on 'high-nitrogen' medium. Although the predominant fatty acyl constituents were the same, there was a decrease in the content of $18: 2$ and a concomitant increase in 18:0 and 18:1 so that all three of these fatty acids were present as approximately $20-30 \%(\mathrm{w} / \mathrm{w})$ of the total cell lipid (see Table 3).

When A. nidulans was grown on 'low-nitrogen' medium for $70 \mathrm{~h}$, differences between the lipid accumulation in the three strains of $A$. nidulans became apparent. Whilst the wild-type and $a c u F 205$ accumulated equivalent amounts of cell lipid (approximately $25 \%$, w/w, of cell dry weight), acuK248 accumulated only half this amount $(12 \%, w / w$, of cell dry weight; see Table 2$)$. This difference did not appear to be the result of impaired growth or glucose metabolism since all three strains achieved similar culture dry weights and cell yield (see Table 2). Qualitatively, the fatty acyl compositions of
Table 3. Major fatty acyl constituents of cell lipid from A. nidulans

Data are presented as mean values from duplicate experiments. UI, unsaturation index $=[\%$ monoene $+2(\%$ diene $)+3$ (\% triene) $] / 100$.

\begin{tabular}{|c|c|c|c|}
\hline \multirow[t]{2}{*}{$\begin{array}{l}\text { Major } \\
\text { fatty acids }\end{array}$} & \multicolumn{3}{|c|}{$\begin{array}{c}\text { Relative } \%(w / w) \text { of total fatty acyl } \\
\text { groups in cell lipid }\end{array}$} \\
\hline & Wild-type & acuF205 & acuK248 \\
\hline \multicolumn{4}{|c|}{ Grown on 'high-nitrogen' medium (HAM) for $40 \mathrm{~h}$} \\
\hline $16: 0$ & $18 \cdot 9$ & $18 \cdot 4$ & $17 \cdot 6$ \\
\hline 18:0 & $5 \cdot 9$ & $6 \cdot 2$ & $6 \cdot 5$ \\
\hline $18: 1$ & $8 \cdot 8$ & $12 \cdot 0$ & $9 \cdot 2$ \\
\hline $18: 2$ & $61 \cdot 0$ & $58 \cdot 8$ & $61 \cdot 1$ \\
\hline UI & $1 \cdot 4$ & $1 \cdot 4$ & $1 \cdot 4$ \\
\hline \multicolumn{4}{|c|}{ Grown on 'low-nitrogen' medium (LAM) for $70 \mathrm{~h}$} \\
\hline $16: 0$ & $22 \cdot 7^{\circ}$ & $22 \cdot 3$ & $19 \cdot 9$ \\
\hline $18: 0$ & $22 \cdot 3$ & $21 \cdot 4$ & $23 \cdot 7$ \\
\hline $18: 1$ & $22 \cdot 9$ & $31 \cdot 2$ & $19 \cdot 0$ \\
\hline $18: 2$ & $29 \cdot 4$ & $22 \cdot 6$ & $34 \cdot 4$ \\
\hline UI & 0.9 & 0.9 & 0.9 \\
\hline
\end{tabular}

the lipid accumulated by the three strains of $A$. nidulans under these conditions were similar, although some variation in the relative contents of $18: 1$ and $18: 2$ was apparent (see Table 3).

When the fungi were cultivated on 'low-nitrogen' medium for $70 \mathrm{~h}$, separation of the cell lipid into neutral lipid, glycolipid and polar lipid fractions demonstrated that the majority of the accumulated lipid was neutral lipid. Neutral lipid (predominantly triacylglycerols) constituted approximately $85 \%(w / w)$ of the lipid in the 
wild-type and $a c u F 205$ and $77 \%(w / w)$ of the lipid in $a c u K 248$. Generally, the fatty acyl compositions of the three lipid fractions were similar to each other and resembled that of the whole-cell lipid for the wild-type and $a c u F 205$ strains. The polar lipid fraction from $a c u \mathrm{~K} 248$, however, possessed a higher percentage of 18:2 and concomitantly less $18: 0$ and $18: 1$ than the other lipid fractions and the whole-cell lipid sample.

\section{Analysis of culture filtrates}

When the fungi were grown on 'high-nitrogen' medium (lipid-non-accumulating conditions), the concentrations of malate in the culture filtrates from all three fungi were similar and low (see Table 2). Under lipid-accumulating conditions (when the fungi were grown on 'lownitrogen' medium), however, both $a c u$ F205 and $a c u \mathrm{~K} 248$ excreted higher levels of malate which were significantly greater than that produced by the wildtype: twofold and fourfold greater, respectively. No citrate was detected in the culture filtrates from any of the fungi.

\section{DISCUSSION}

Generally the activities of malic enzyme detected throughout this work were low, which is in agreement with the work of McCullough \& Roberts (1974), who reported low activity of malic enzyme when $A$. nidulans was cultivated on glucose.

The enzymological data demonstrated that, of the enzymes examined, acuK248 appeared to be lacking only malic enzyme activity. This is in accord with the conclusion that $a c u K 248$ carries a mutation in the malic enzyme structural gene (McCullough \& Roberts, 1974). Although the malic enzyme activity detected in acuF205 was higher than that in the wild-type the difference was small and not significant. It appeared therefore that the greatly elevated malic enzyme activity reported for this strain (McCullough \& Roberts, 1974) may only be evident when malic enzyme activity is stimulated by transfer of biomass to acetate-containing medium.

The lower activities of pyruvate carboxylase and pyruvate decarboxylase in $a c u K 248$ (which were only $20 \%$ of that in the wild-type strain) indicated that the absence of malic enzyme activity affected pyruvate metabolism in this strain. This would be in accord with the conclusion of McCullough \& Roberts (1974) that malic enzyme plays a role in the metabolism of pyruvate in $A$. nidulans, but we would suggest that this is of only minor metabolic significance in glucose-grown cells.

It is possible that the pyruvate decarboxylase activity detected was due to the decarboxylase activity of a dissociated pyruvate dehydrogenase complex. As pyruvate dehydrogenase activity was not detectable this possibility was not readily precluded. It is thought probable, however, that the pyruvate decarboxylase activity was due to the presence of a discrete pyruvate decarboxylase, associated with the growth of $A$. nidulans as pellets in shake flasks, rather than as a homo- geneous culture. The mycelia in the centre of these pellets were likely to experience $\mathrm{O}_{2}$-limited conditions and thus possess the enzymes associated with the anaerobic metabolism of glucose, including pyruvate decarboxylase.

Neither pyruvate carboxylase nor pyruvate decarboxylase (either as a discrete enzyme or as part of the pyruvate dehydrogenase complex) has previously been implicated as having an important role in lipid metabolism. Therefore the differences noted in this study, concerning storage lipid biosynthesis by strains of $A$. nidulans, are thought to be a result of the presence and absence of malic enzyme activity.

When A. nidulans was grown on 'high-nitrogen' medium for $40 \mathrm{~h}$ the lipid content of the biomass was low and essentially identical in all three strains regardless of their malic enzyme activity. It is suggested, therefore, that under these conditions the cell lipid produced was crucial to the metabolic functioning of the cell and that the production of this 'metabolically active' lipid was not limited by the activity of malic enzyme. The fatty acyl composition of this lipid was interesting in that it contained a very high proportion of 18:2 (approximately $60 \%, w / w$, of the total lipid), suggesting that 18:2 was important for the metabolic activity of $A$. nidulans, as well as indicating that malic enzyme was not involved in fatty acid desaturation.

When the fungi were grown on 'low-nitrogen' medium to promote the accumulation of storage lipid, the possession of malic enzyme activity appeared to be a key factor to engender lipid accumulation. The strain of $A$. nidulans lacking malic enzyme activity (acuK248) accumulated only half as much lipid as the strains possessing malic enzyme (the wild-type and $a c u F 205$ ). The fact that $a c u K 248$ did accumulate some storage lipid showed that although malic enzyme activity was required for maximal production of storage lipid, the lack of this enzyme could be overcome to some degree at least.

It has been suggested that the function of malic enzyme in lipid biosynthesis is to supply NADPH for fatty acid synthase and desaturases (Evans \& Ratledge, 1985; Kendrick \& Ratledge, 1992a). In acuK248, although malic enzyme was absent, other NADPH-generating enzymes - $\mathrm{NADP}^{+}$-dependent isocitrate dehydrogenase, glucose-6-phosphate dehydrogenase and 6-phosphogluconate dehydrogenase - were all detected at high activities. Indeed, in all strains of $A$. nidulans, the activities of these enzymes were many times that of malic enzyme. Thus it is difficult to envisage a deficiency of NADPH for lipid biosynthesis based solely on the absence of malic enzyme and if there exists a single cellular pool of NADPH. The activity of malic enzyme could only limit storage lipid biosynthesis in regard to the supply of reducing power if there was a separate and discrete cellular pool of NADPH produced by malic enzyme and preferentially channelled into fatty acid synthesis probably by direct coupling to fatty acid synthase. 
The possibility that the lack of malic enzyme in acuK248 was limiting storage lipid formation by, in some way, interfering with the production of cytosolic acetyl-CoA from citrate, as described by Evans \& Ratledge (1985), perhaps by the accumulated malate inhibiting ATP: citrate lyase activity, was discounted. Although malate did accumulate in the culture filtrate of $a c u \mathrm{~K} 248$, a similar accumulation was observed in acuF205 (albeit to a lesser extent) even in the presence of malic enzyme activity and this did not adversely affect lipid accumulation. Furthermore, malate at the concentrations detected, in the culture filtrate samples, did not cause a substantial inhibition of ATP : citrate lyase activity in $A$. nidulans as determined in vitro.

Although acuK248 accumulated less storage lipid than the strains possessing malic enzyme, the lack of malic enzyme activity in this strain did not adversely affect fatty acid desaturation. The unsaturation index (UI) for the lipid accumulated by all three strains was identical regardless of the presence or absence of malic enzyme activity. Thus there was no evidence of a role for malic enzyme in the desaturation of fatty acids as has been reported for the oleaginous fungus Mucor circinelloides (Kendrick \& Ratledge, 1992a).

The data obtained in this study thus demonstrate that malic enzyme activity is important for the accumulation of storage lipid in A. nidulans and support the hypothesis that this enzyme is important in the generation of NADPH for lipid biosynthesis in oleaginous organisms (Evans \& Ratledge, 1985). To the best of our knowledge, this is the first report to demonstrate a direct link between malic enzyme activity and the degree of lipid accumulation by an oleaginous fungus.

Malic enzyme did not appear to be important, however, for the synthesis of the lipid required for the metabolic activity of the cell. This is analogous to the requirement of ATP : citrate lyase by oleaginous yeasts for significant lipid yields (Botham \& Ratledge, 1979) whilst nonoleaginous yeasts lacking this enzyme still generated the lipid required for metabolic purposes.

\section{ACKNOWLEDGEMENTS}

Grateful thanks are extended to Dr H. Sealy-Lewis (Department of Biological Sciences, University of Hull) for the kind donation of the strains of A. nidulans used during this study, also to Mrs M. Ewing for her expert technical assistance. This work was supported by a research grant (21.27.67) from the Biotechnology and Biological Sciences Research Council, UK.

\section{REFERENCES}

Armitt, S., McCullough, W. \& Roberts, C. F. (1976). Analysis of acetate non-utilizing ( $a c u)$ mutants in Aspergillus nidulans. J Gen Microbiol 92, 263-282.

Botham, P. A. \& Ratledge, C. (1979). A biochemical explanation for lipid accumulation in Candida 107 and other oleaginous micro-organisms. J Gen Microbiol 114, 361-375.
Bradford, M. M. (1976). A rapid and sensitive method for the quantitation of microgram quantities of protein utilizing the principle of protein-dye binding. Anal Biochem 72, 248-254.

Butte, W. (1983). Rapid method for the determination of fatty acid profiles from fats and oils using trimethylsulphonium hydroxide for transesterification. J Chromatogr 261, 142-145.

Das, T. K. \& Sen, K. (1983). Induced mutation developing $\Delta^{9}$ desaturase defective unsaturated fatty acid requiring mutants of Aspergillus nidulans IMI 72731. Ind J Exp Biol 21, 339-342.

Evans, C. T. \& Ratledge, C. (1985). Possible regulatory roles of ATP: citrate lyase, malic enzyme and AMP deaminase in lipid accumulation by Rhodosporidium toruloides CBS 14. Can J Microbiol 31, 1000-1005.

Folch, J., Lees, M. \& Sloane-Stanley, G. H. (1957). A simple method for the isolation and purification of total lipides from animal tissues. J Biol Chem 226, 497-509.

Hsu, R. Y. \& Lardy, H. A. (1969). Malic enzyme. Methods Enzymol 13, 230-235.

Kendrick, A. \& Ratledge, C. (1992a). Desaturation of polyunsaturated fatty acids in Mucor circinelloides and the involvement of the novel membrane-bound malic enzyme. Eur $J$ Biochem 209, 667-673.

Kendrick, A. \& Ratledge, C. (1992b). Lipids of selected moulds grown for the production of $n-3$ and $n-6$ polyunsaturated fatty acids. Lipids 27, 15-20.

Langdon, R. G. (1966). Glucose 6-phosphate dehydrogenases from erythrocytes. Methods Enzymol 9, 126-131.

McCullough, W. \& Roberts, C. F. (1974). The role of malic enzyme in Aspergillus nidulans. FEBS Lett 41, 238-242.

McCullough, W., Payton, M. A. \& Roberts, G. F. (1977). Carbon metabolism in Aspergillus nidulans. In Genetics and Physiology of Aspergillus, pp.97-129. Edited by J. E. Smith \& J. A. Pateman. London: Academic Press.

Ochoa, S. (1955). Malic dehydrogenase from pig heart. Methods Enzymol 1, 735-739.

Pontecorvo, G., Roper, J. A., Hemmans, L. J., MacDonald, K. D. \& Bufton, A. W. (1953). The genetics of Aspergillus nidulans. Adv Genet 5, 141-238.

Potremoli, S. \& Grazi, E. (1966). 6-Phosphogluconate dehydrogenase - crystalline. Methods Enzymol 9, 137-141.

Reed, L. J. \& Willms, C. R. (1966). Purification and resolution of the pyruvate dehydrogenase complex (Escherichia coli). Methods Enzymol 9, 258-259.

Seubert, W. \& Weicker, H. (1969). Pyruvate carboxylase from Pseudomonas. Methods Enzymol 13, 258-260.

Sharma, N. D., Mathur, J. M. S., Saxena, B. S. \& Sen, K. (1981). Fatty acid composition of oil synthesized by Aspergillus nidulans. Folia Microbiol 26, 314-316.

Srere, P. A. (1959). The citrate cleavage enzyme. 1. Distribution and purification. J Biol Chem 234, 2544-2547.

Williamson, J. R. \& Corkey, B. E. (1969). Assays of intermediates of the citric acid cycle and related compounds by fluorometric enzyme methods. Methods Enzymol 13, 434-513.

Zink, M. W. (1972). Regulation of the two malic enzymes in Neurospora crassa. Can J Microbiol 18, 611-617.

Zink, M. W. \& Katz, J. S. (1973). Malic enzyme of Fusarium oxysporum. Can J Microbiol 19, 1187-1196.

Received 1 July 1996; revised 28 August 1996; accepted 5 September 1996. 